Article

\title{
Chronology of Four Climbing Dune Outcrops on the Atlantic Coast of Galicia (NW Spain) Linked to the Sea Level Fall during the MIS6 and MIS4 Isotopic Stages
}

\author{
Carlos Arce-Chamorro*(D), Juan Ramón Vidal-Romaní (D) and Jorge Sanjurjo-Sánchez (iD
}

\begin{abstract}
Grupo Interdisciplinar de Patrimonio Cultural y Geológico 'CULXEO', Instituto Universitario de Xeoloxía "Isidro Parga Pondal", Edificio de Servicios Centrales de Investigación (ESCI), Campus de Elviña, Universidade da Coruña, 15071 A Coruña, Spain; juan.vidal.romani@udc.es (J.R.V.-R.); jorge.sanjurjo.sanchez@udc.es (J.S.-S.)

* Correspondence: carlos.arce@udc.es
\end{abstract}

check for updates

Citation: Arce-Chamorro, C.;

Vidal-Romaní, J.R.; Sanjurjo-Sánchez, J. Chronology of Four Climbing Dune Outcrops on the Atlantic Coast of Galicia (NW Spain) Linked to the Sea Level Fall during the MIS6 and MIS4 Isotopic Stages. J. Mar. Sci. Eng. 2022, 10, 312. https://doi.org/10.3390/ jmse10030312

Academic Editor: João Miguel Dias

Received: 1 February 2022

Accepted: 18 February 2022

Published: 23 February 2022

Publisher's Note: MDPI stays neutral with regard to jurisdictional claims in published maps and institutional affiliations.

Copyright: (c) 2022 by the authors. Licensee MDPI, Basel, Switzerland. This article is an open access article distributed under the terms and conditions of the Creative Commons Attribution (CC BY) license (https:// creativecommons.org/licenses/by/ $4.0 /)$.

\begin{abstract}
Numerous sandy deposits, interpreted as the remains of old climbing dunes, are preserved on the cliffy coast of Galicia (northwest Spain). These deposits can be found both in open coastal areas and in the interior of the Galician Rias. In this paper, a formation age is established for four aeolianite outcrops dating back to $166 \pm 9 \mathrm{ka}, 131 \pm 6 \mathrm{ka}, 128 \pm 18 \mathrm{ka}$ and $62 \pm 3 \mathrm{ka}$, using the IRSL $_{290}$ signal of feldspars. These sands were mobilised by coastal winds from a sea level lower than the current one during MIS6 and MIS4. The sea level fall during these regressive episodes shifted the coastline several kilometres away from its current position. This favoured the action of the wind blowing over the emerged coastal strip, which acted as a source area for aeolian sands. During warmer episodes, such as the Eemian and the Holocene, the advance of the sands onto the coast was progressively reduced as the sea level rose and the oceanic waters flooded the continental shelf.
\end{abstract}

Keywords: coastal aeolianites; climbing dunes; pIR-IRSL dating; Middle and Upper Pleistocene; glacio-eustasy; aeolian accretion; Atlantic coast of Galicia (NW Spain)

\section{Introduction}

On the Atlantic coast of Galicia (NW Spain) (Figure 1), there are fossilised sandy deposits that are preserved along stretches of low coastlines and also in areas of rocky coastal cliffs of different elevations, reaching altitudes of $+45 \mathrm{~m}$ (or more) above the present sea level (apsl) [1]. In previous literature, the aeolian coastal sediments of Galicia were considered to be beach deposits [2]. Due to the impossibility of establishing a radiocarbon chronology for these siliciclastic materials, their position with respect to sea level was used to obtain a relative age for them. The simplest idea was that they were all beach levels; thus, the higher the elevation, the older they were and therefore, the sea reached a hypothetically higher level. However, this reasoning was invalidated by the fact that, as in this case, there are aeolian deposits that can only be related to regressive marine episodes. This altitudinal criterion became even more confusing when considering the rise of the Galician coast during the last $650 \mathrm{ka}$ [3]. More recently, some authors have identified them as aeolian sands [4-6] and have interpreted the aeolianites as the remains of sedimentary formations formed and repeatedly destroyed during the glacioeustatic oscillations of the Pleistocene [7]. At that time, the unavailability of adequate dating techniques did not allow for a more precise chronology.

A comprehensive characterisation by Gutiérrez-Becker [1] concluded that these sandy deposits have an aeolian origin, describing them as well-selected, thin $(<5 \mathrm{~m})$ and azoic siliciclastic wedges that correspond to old climbing dunes. This has been confirmed by the most recent OSL chronology that has been established for some of these aeolian outcrops [8], which indicates that the dune fields and climbing dunes reached the present coastline more than $20 \mathrm{ka}$ ago, with a shoreline $-100 \mathrm{~m}$ below present sea level (bpsl). According 
to the local sedimentary record (as discussed later in Section 5), this process of aeolian sand accretion on this steep coastline continued during the Holocene transgression $[9,10]$, only stopping when the sea reached more recent levels and flooded the sand's source areas. In general, under the humid temperate climate of the north Atlantic peninsular coast [11], the most recent $(<5 \mathrm{ka})$ dunes and climbing dunes have been stabilised by terrestrial vegetation [1,12] and at present these dunes are severely affected by aeolian erosion processes during storms, with the development of blowout forms - to which must also be added wave erosion as the sea level rises [13]. In other cases, these sediments have been fossilised by slope deposits in some coastal cliff sections [1,14], which has allowed for their preservation and subsequent study —as in the present case (Figure 2).

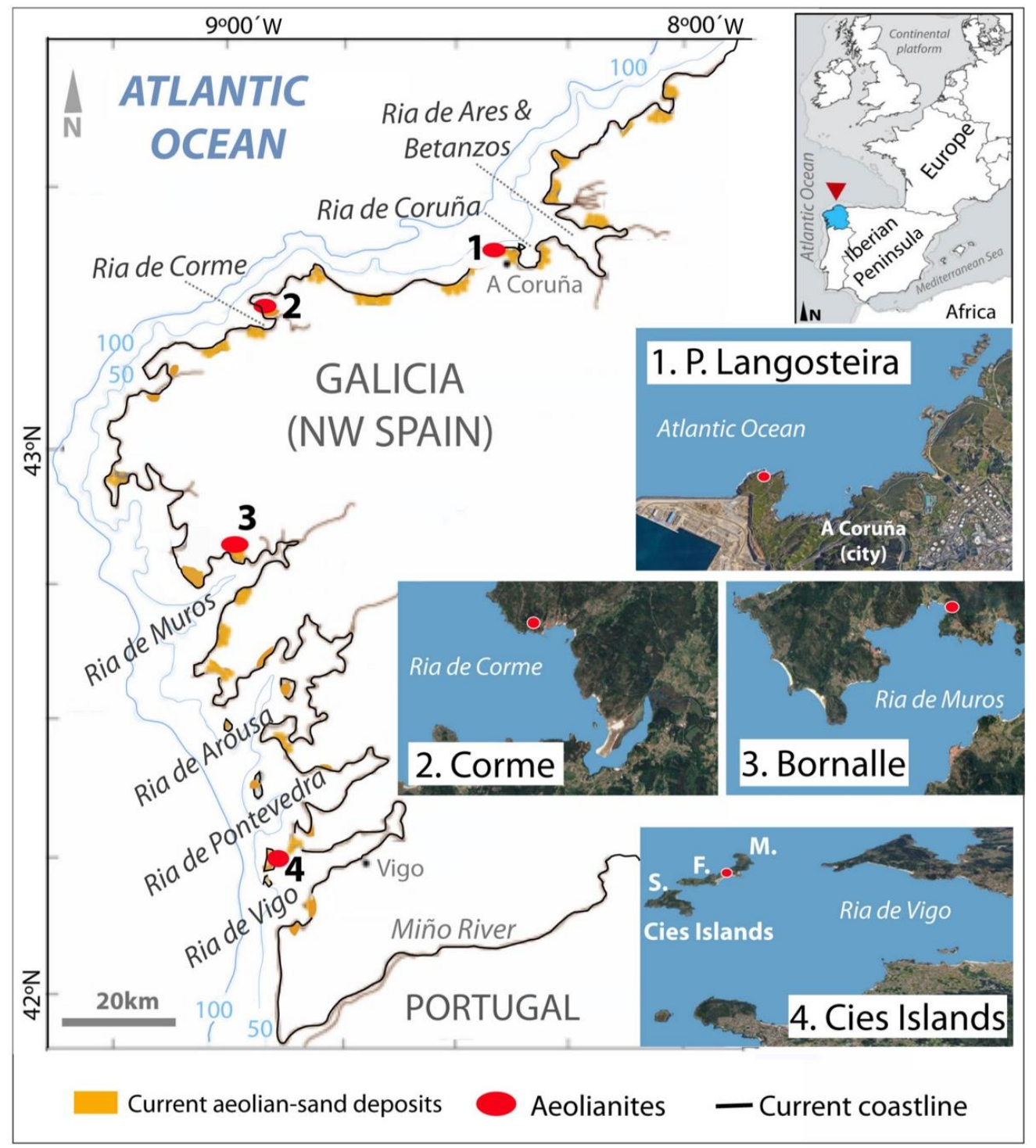

Figure 1. Location map. Current aeolian sand dunes (yellow areas) on the Atlantic coast of Galicia (NW Spain) and the location of the old climbing dunes (red dots) dated in this paper. (M) Monteagudo, (F) Faro and (S) San Martiño of the Cíes Islands. The $100 \mathrm{~m}$ and $50 \mathrm{~m}$ isobaths are also shown.

The main objective of this paper is to establish the age of deposition for some of the aeolianite deposits along the Atlantic margin of Galicia (NW Iberian Peninsula), as described above and previously characterised by Gutiérrez-Becker [1]. The OSL signal of quartz is saturated for such deposits; thus, it is appropriate to use infrared stimulated luminescence (IRSL) on k-feldspars. We used post-infrared IRSL (also denoted by pIR-IRSL). The obtained chronology allows for the extending of our knowledge about the formation of 
the old climbing dunes that are related to regressive episodes and the better understanding of the geomorphological processes that modelled the coastal relief, as well as the evolution of coastal dynamics at the end of the Pleistocene.
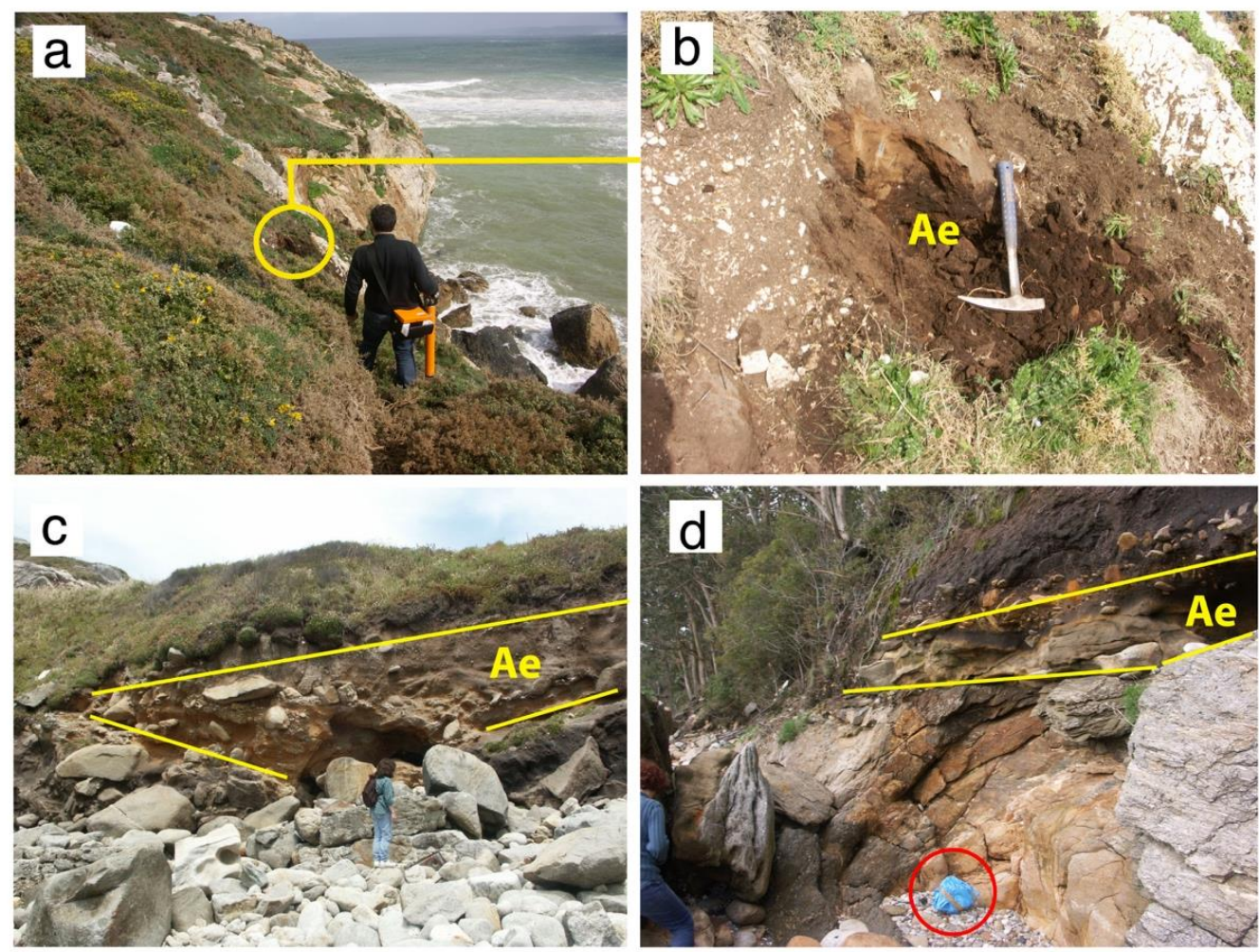

Figure 2. Images of the fossilised climbing dune outcrops Aeolian wedges (Ae) from the climbing dunes of Punta Langosteira (a,b), Corme (c) and Bornalle (d), usually covered by slope deposits and terrestrial vegetation [1]. The red circle shows a sampled brick (d).

\section{Study Area}

The Atlantic coast of Galicia (NW Spain), which is more than $1700 \mathrm{~km}$ long, is defined by a rocky coastline of rias and cliffs (Figures 1 and 2a). The rias are wide estuaries with their primary origins $[15,16]$ being fluvial valleys flooded during the current post-glacial transgressive episode. The cliffs are of tectonic origin [17] and reach altitudes of up to $+600 \mathrm{~m}$ (apsl), resulting in the irregular and very steep morphology of this coastal relief. At the current sea level, a high-energy marine dynamic develops in the open coastal areas due to strong coastal winds, mainly from the S-SW direction [18]. The continental shelf has a very regular and low-gradient surface, with a width of approximately $20 \mathrm{~km}$ when the $-200 \mathrm{~m}$ isobath (bpsl) is considered as the boundary between the shelf and the continental slope [19].

The location, from north to south, of the sandy deposits that are studied in this paper (Figures 1 and 2) is described as follows. The aeolianite from Punta Langosteira $\left(43^{\circ} 21^{\prime} 36^{\prime \prime} \mathrm{N}\right.$; $8^{\circ} 29^{\prime} 27^{\prime \prime} \mathrm{W}$ ) is located in a very steep area of open coast between $+5 \mathrm{~m}$ and $+10 \mathrm{~m}$ (apsl) on the (middle) cliffs near the outer harbour of Arteixo (A Coruña) (Figures 1 and 2a,b). The aeolianite from Corme $\left(43^{\circ} 15^{\prime} 45^{\prime \prime} \mathrm{N} ; 8^{\circ} 58^{\prime} 04^{\prime \prime} \mathrm{W}\right.$ ) (Figures 1 and $2 \mathrm{c}$ ) is located at $+12 \mathrm{~m}$ (apsl) in a cliff area inside the Ria de Corme and Laxe near the most recent climbing dune in Ponteceso (A Coruña), the height of which reaches more than $100 \mathrm{~m}$ (Figure 3a) - as do other climbing dunes on the coast of Galicia (Figure 3) - and which is covered with terrestrial vegetation, except in the areas where blowout erosive formations develop (Figure 3 ). The aeolianite from Bornalle $\left(42^{\circ} 47^{\prime} 47^{\prime \prime} \mathrm{N} ; 9^{\circ} 00^{\prime} 42^{\prime \prime} \mathrm{W}\right)$ is located at $+2 \mathrm{~m}$ (apsl) but in the interior of the Ria de Muros (A Coruña, Galicia) (Figures 1 and 2d). Finally, the aeolianite from the Lagoa dos Nenos on the Cíes Islands- $\left(42^{\circ} 13^{\prime} 29^{\prime \prime} \mathrm{N} ; 8^{\circ} 54^{\prime} 17^{\prime \prime} \mathrm{W}\right)$ is located on the 
most protected eastern slope of the Cíes Islands archipelago (Figure 1) - at the mouth of the Vigo estuary (Pontevedra, Galicia). This old climbing reaches heights between $+6 \mathrm{~m}$ and $+10 \mathrm{~m}$ (apsl) and is located very close to the dune field that dates back between $25 \mathrm{ka}$ and $4 \mathrm{ka}$ [9] and to another climbing dune located at $+40 \mathrm{~m}$ (apsl) that was formed between $35 \mathrm{ka}$ and $17 \mathrm{ka}[8]$.
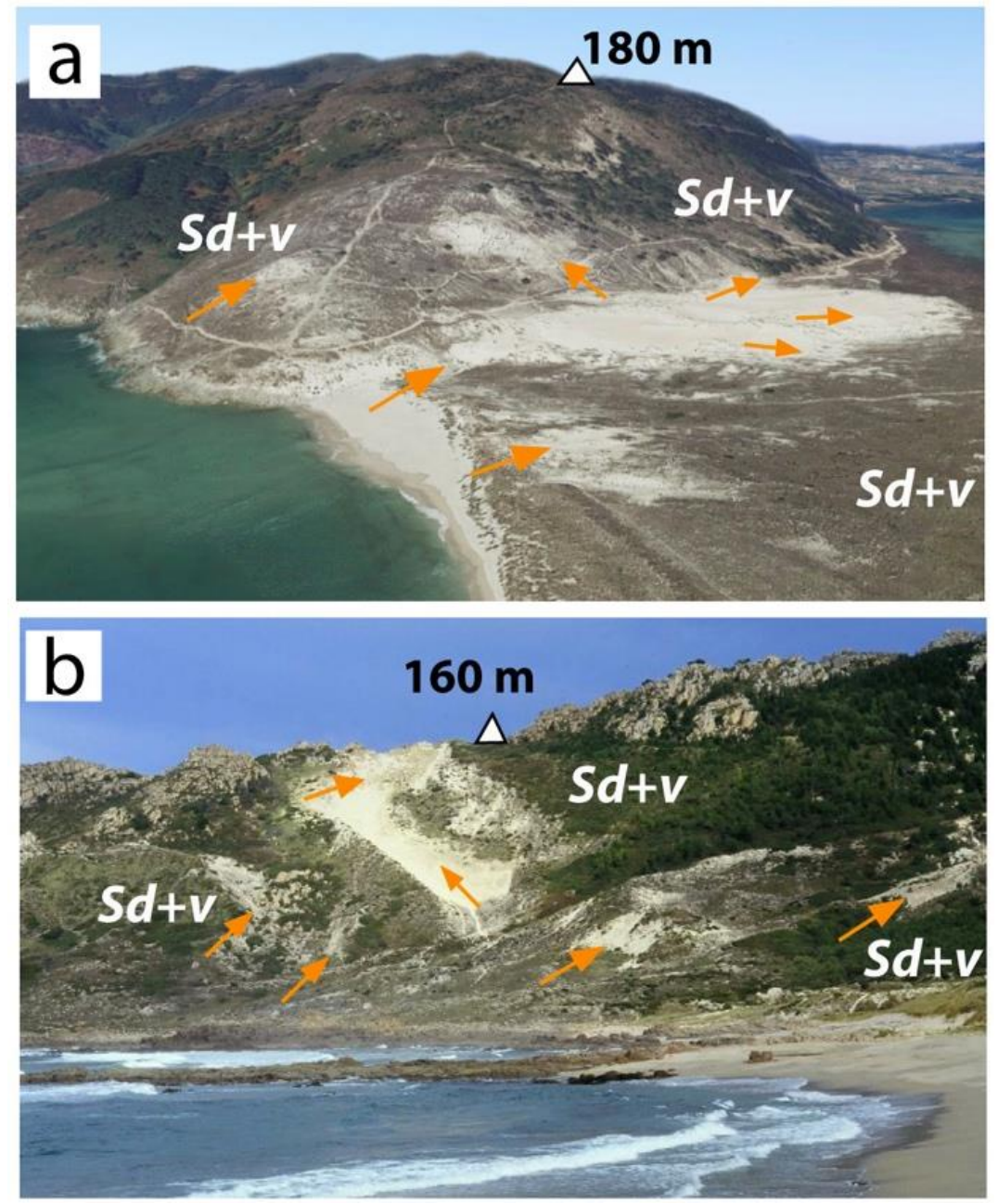

Figure 3. Relic climbing dunes from (a) Ponteceso $\left(43^{\circ} 14^{\prime} \mathrm{N} ; 8^{\circ} 56^{\prime} \mathrm{W}\right)$ and (b) Trece $\left(43^{\circ} 11^{\prime} \mathrm{N}\right.$; $9^{\circ} 08^{\prime} \mathrm{W}$ ) (WGS84) on the coast of A Coruña (Galicia, NW Spain), over $+150 \mathrm{~m}$ above present sea level. Sand dunes (Sd) are currently covered by terrestrial vegetation (v) and even trees. The arrows indicate blowout erosional formations produced by wind during storm events.

\section{Materials and Methods}

The Punta Langosteira and Lagoa dos Nenos samples were extracted by hammering steel cores (large: $20 \mathrm{~cm}, \varnothing=10 \mathrm{~cm}$ ) and the Corme and Bornalle samples were extracted as $50 \mathrm{~cm}^{3}$ bricks (Figure 2d). In the luminescence laboratory of the University of A Coruña [20], the outer part of the cores was removed under subdued red light and the central part was dried and sieved. Coarse sand grains (180-250 $\mu \mathrm{m})$ were treated with $\mathrm{HCl}$ and $\mathrm{H}_{2} \mathrm{O}_{2}$ to remove carbonates and organic matter, respectively. K-feldspars grains were extracted through centrifugation in a high-density solution of sodium polytungstate $\left(2.58 \mathrm{~g} / \mathrm{cm}^{3}\right)$ and were then treated with HF (10\%). The k-feldspar signals were measured on small multigrain aliquots mounted on stainless steel discs in a Riso-DA15 automated TL/OSL reader that was equipped with IR (blue light) emitting diodes (LEDs) $(470 \pm 30 \mathrm{~nm})$ for stimulation and a 9235QA photomultiplier, using a combination of Schott-BG 39 and Corning 7-59 glass filters between the photomultiplier and the samples. To irradiate the samples, beta doses 
were used with a ${ }^{90} \mathrm{Sr} /{ }^{90} \mathrm{Y}$ source, which provided a dose rate of $0.120 \pm 0.003 \mathrm{~Gy} / \mathrm{s}$. The first five seconds of the IRSL signals were integrated and the background was removed in the last $25 \mathrm{~s}$.

To estimate the equivalent doses $\left(D_{e} s\right)$, a modified single aliquot regenerative dose (SAR) protocol $[21,22]$ was used to assess the $D_{e} s$ by measuring a IRSL signal at $50{ }^{\circ} \mathrm{C} / 200 \mathrm{~s}$ (IRSL ${ }_{50}$ ) and a second IRSL signal at $290^{\circ} \mathrm{C} / 200 \mathrm{~s}\left(\mathrm{IRSL}_{290}\right.$ ), including pre-heat treatment $\left(320{ }^{\circ} \mathrm{C} / 60 \mathrm{~s}\right.$ ) and IR bleaching at $325{ }^{\circ} \mathrm{C} / 100 \mathrm{~s}$. Dose recovery tests were performed. Residual signals from feldspars were measured on aliquots that had been bleached for 1 week and the estimated residual doses were subtracted from the obtained $D_{e} s$. Anomalous fading tests were conducted following Auclair et al. [23]. All signals were measured and normalised with a test dose $\left(\mathrm{L}_{\mathrm{x}} / \mathrm{T}_{\mathrm{x}}\right)$ on used aliquots after different storage times between the irradiation and the measurements and with an extra pre-heat step in between. The obtained $\mathrm{L}_{\mathrm{x}} / \mathrm{T}_{\mathrm{x}}$ were plotted against the time delay (log scale) between the irradiation and measurement periods to assess the $g$-values and to calculate the fading-corrected ages following Huntley and Lamothe [24] by RLumShiny [25].

The dose rates $\left(D_{r} s\right)$ were estimated using low-background gamma spectrometry on bulk samples. Marinelli beakers were used, and the measurements were performed in a coaxial Camberra-XTRA gamma detector (Ge-Intrinsic), model GR6022, within a $10 \mathrm{~cm}$ thick lead shield. The conversion factors from Guerin et al. [26] were used. The internal beta dose rate activity from ${ }^{40} \mathrm{~K}$ was calculated based on an assumed effective potassium content of $12.5 \pm 0.5 \%$ [27] and assuming an effective $D_{r-a l p h a}$ auto-irradiation of $0.1 \pm 0.05 \mathrm{~Gy} / \mathrm{ka}$ [28]. The water content and water saturation values were assessed in the laboratory for all samples to estimate an average water content and the cosmic dose rates were calculated according to Prescott and Hutton [29].

\section{Results}

\subsection{Dose Rate $\left(D_{r}\right)$}

To estimate the dose rates $\left(D_{r} s\right)$ (Table 1$)$, a percentage of the water content during the burial time of $20 \pm 2 \%$ was assumed for the Lagoa dos Nenos, Punta Langosteira and Bornalle samples and $30 \pm 3 \%$ for the Corme sample (Table 1), based on the moisture and saturation data calculated for each sample. The proportion of fine and medium sand in these materials was higher than $90 \%$ [1], so drainage conditions were favourable, thus reducing $D_{r}$ attenuation by interstitial water content [30]. Although a high degree of homogeneity has been described in these outcrops, which would minimise variations related to beta dosimetry [31], a slight disequilibrium in the ${ }^{238} \mathrm{U}$ series [32,33] was observed in all samples (Table 1). Considering that this disequilibrium occurred over the burial time, the correction made was calculated from the maximum and minimum values, assuming both equilibrium and disequilibrium, (Table 1) and the uncertainty as the sum of the errors. The corrected $D_{r} S$ for these samples ranged between 3.6 and $4.5 \mathrm{~Gy} / \mathrm{ka}$ (Table 1).

Table 1. Dose rate $\left(D_{r}\right)$. Radioisotopic activity from the 238-U, 232-Th and 40-K decay series. $D_{r}$-Total assuming equilibrium (e) and disequilibrium (d) between 238-U and 226-Ra and the corrected $D_{r}$-Total $(\mathrm{Gy} / \mathrm{ka})$. W, the percentage of estimated water saturation during the burial time.

\begin{tabular}{|c|c|c|c|c|c|c|c|}
\hline Samples & $\begin{array}{c}238-\mathrm{U} \\
(\mathrm{Bq} / \mathrm{kg})\end{array}$ & $\begin{array}{r}226-\mathrm{Ra} \\
(\mathrm{Bq} / \mathrm{kg})\end{array}$ & $\begin{array}{l}232-\mathrm{Th} \\
\text { (Bq/kg) }\end{array}$ & $\begin{array}{c}40-\mathrm{K} \\
(\mathrm{Bq} / \mathrm{kg})\end{array}$ & W (\%) & $\begin{array}{c}D_{r} \text {-Total } \\
\text { (Gy/ka) }\end{array}$ & $\begin{array}{c}\text { Corrected } \\
D_{r} \text {-Total }\end{array}$ \\
\hline Corme & $53 \pm 13$ & $16 \pm 1$ & $13 \pm 1$ & $552 \pm 51$ & $30 \pm 3$ & $\begin{array}{l}\text { (e) } 3.9 \pm 0.3 \\
\text { (d) } 3.3 \pm 0.2\end{array}$ & $3.7 \pm 0.8$ \\
\hline Lagoa dos Nenos & $60 \pm 18$ & $21 \pm 2$ & $18 \pm 4$ & $756 \pm 41$ & $20 \pm 2$ & $\begin{array}{l}\text { (e) } 4.8 \pm 0.4 \\
\text { (d) } 4.1 \pm 0.2\end{array}$ & $4.5 \pm 0.6$ \\
\hline Punta Langosteira & $48 \pm 12$ & $21 \pm 1$ & $43 \pm 3$ & $539 \pm 50$ & $20 \pm 2$ & $\begin{array}{l}\text { (e) } 3.9 \pm 0.2 \\
\text { (d) } 3.4 \pm 0.2\end{array}$ & $3.7 \pm 0.6$ \\
\hline Bornalle & $24 \pm 5$ & $30 \pm 1$ & $11 \pm 1$ & $676 \pm 63$ & $20 \pm 2$ & $\begin{array}{l}\text { (e) } 3.7 \pm 0.3 \\
\text { (d) } 3.5 \pm 0.2\end{array}$ & $3.6 \pm 0.4$ \\
\hline
\end{tabular}




\subsection{Equivalent Dose $\left(D_{e}\right)$ and Ages}

The sandy aeolian sediments studied here are characterised by high sorting [34] and, unlike other aeolian materials such as loess, show a good degree of signal bleaching due to good exposure to sunlight, which reduces the likelihood of the overestimation of the dose equivalent to burial time [35]. The IRSL 50 and IRSL $_{290}$ signals were intense, with fast decay curves and growth curves suitable for interpolation (Figure 4a). The estimated doses for each aliquot showed a symmetrical distribution, with a wide dispersion and a good fit to a normal (Figure $4 \mathrm{~b}$ ), with an associated error of between $5 \%$ and $15 \%$. The recovery tests results were within the appropriate range (0.9-1.1) for the use of the (modified) SAR.
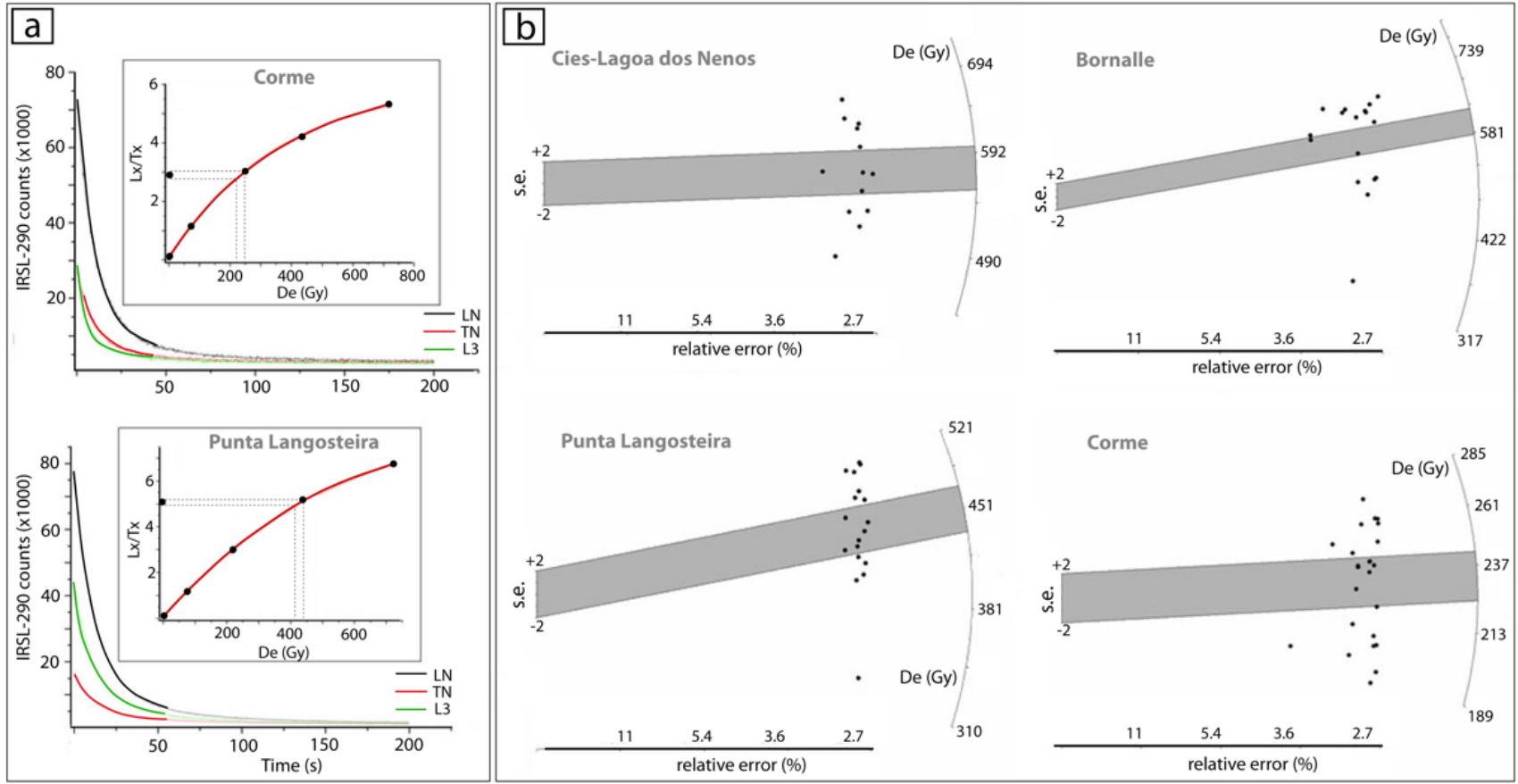

Figure 4. IRSL signal from feldspars and $D_{e} s$ distribution. (a) Some examples of the fast decay curves of the IRSL 290 signal, recorded during the IR stimulus time, from the aeolian samples dated in the present paper: LN, natural IRSL 290 signal; TN, natural IRSL 290 signal from test dose; L3, regenerated IRSL $_{290}$ in the third cycle of the modified SAR for feldspars [22]. Inset shows the interpolation of the normalised natural signal in the growth curve constructed from the normalised regenerated signals $(\mathrm{Lx} / \mathrm{Tx})$, thus calculating an estimate of the equivalent dose $\left(D_{e}\right)$. (b) Radial plots showing the $( \pm 2 \sigma)$ standard error (grey area) of the standard estimate (s.e.) from CAM [36], the relative error (\%) and the $D_{e} s$ (Gy) from each aliquot (black dots).

The $D_{e} s$ of each sample (as summarised in Table 2) was calculated using the weighted mean from the central age model (CAM) [36]. The anomalous fading tests provided variable $g$-values (Table 2). The Corme sample showed no significant fading, and a similar $D_{e}$ was estimated from the IRSL $_{50}$ and IRSL $_{290}$ signals, with the corrected ages of $59 \pm 13 \mathrm{ka}$ and $62 \pm 14 \mathrm{ka}$, respectively (Table 2). For the Lagoa dos Nenos sample, a g-value of $5.2 \pm 1.1$ was observed in the IRSL 50 signal, calculating an apparent age of $79 \pm 11 \mathrm{ka}$ and a corrected age of $153 \pm 58 \mathrm{ka}$. The IRSL 290 signal of this sample showed no fading ( $g$-value $<0.1)$, with an age $128 \pm 18 \mathrm{ka}$. The Punta Langosteira sample had a $g$-value of 0.5 for the IRSL 50 signal, with an apparent age of $95 \pm 16 \mathrm{ka}$ and a corrected age of $100 \pm 16 \mathrm{ka}$. The IRSL 290 signal for this sample showed no fading, with an age of $131 \pm 25 \mathrm{ka}$. Finally, the IRSL 50 signal from the Bornalle sample had a $g$-value of $2.3 \pm 0.5$, with an apparent age of $139 \pm 17 \mathrm{ka}$ and a corrected age of $176 \pm 25 \mathrm{ka}$. The IRSL 290 signal from the Bornalle sample had a $g$-value of 0.1 , with an apparent age of $151 \pm 8 \mathrm{ka}$ and a corrected age of $166 \pm 20 \mathrm{ka}$. 
Table 2. $D_{e} s$ and corrected ages. $D_{r}$, the corrected dose rate; $\mathrm{N}$, the number of aliquots accepted/analysed; $O D$, the percentage of overdispersion; OD-Rec., the percentage of overdispersion from the recovery test; $D_{e}$, the equivalent dose estimated by the CAM model. The estimated fading values $\left(g\right.$-value $=g$ ) for the IRSL 50 and IRSL $_{290}$ signals are indicated: Age, apparent and corrected age (ka, kiloannum $=1000$ years).

\begin{tabular}{|c|c|c|c|c|c|c|c|}
\hline \multirow{2}{*}{ Samples } & \multirow{2}{*}{$\begin{array}{c}D_{r} \\
\text { (Gy/ka) }\end{array}$} & \multirow{2}{*}{$\mathbf{N}$} & \multirow{2}{*}{$\begin{array}{l}O D \\
(\%)\end{array}$} & \multirow{2}{*}{$\begin{array}{l}\text { OD-Rec. } \\
(\%)\end{array}$} & \multirow{2}{*}{$D_{e}(\mathrm{~Gy})$} & \multicolumn{2}{|c|}{ Age (ka) } \\
\hline & & & & & & Apparent & Corrected \\
\hline \multirow{2}{*}{ Corme } & \multirow{2}{*}{$3.7 \pm 0.8$} & \multirow{2}{*}{$24 / 24$} & & & $\begin{array}{c}\text { IRSL }_{50} \\
(\mathrm{~g}<0.1) \\
217 \pm 12\end{array}$ & $=$ & $59 \pm 13$ \\
\hline & & & $11 \pm 2$ & $<5$ & $\begin{array}{l}\mathrm{IRSL}_{290} \\
(\mathrm{~g}<0.1) \\
231 \pm 7\end{array}$ & $=$ & $62 \pm 3$ \\
\hline \multirow{2}{*}{$\begin{array}{l}\text { Lagoa dos } \\
\text { Nenos }\end{array}$} & \multirow{2}{*}{$4.5 \pm 0.6$} & \multirow{2}{*}{$17 / 17$} & & & $\begin{array}{c}\text { IRSL }_{50} \\
(\mathrm{~g}=5.2 \pm 1.1) \\
354 \pm 15\end{array}$ & $79 \pm 11$ & $153 \pm 58$ \\
\hline & & & $11 \pm 3$ & $<5$ & $\begin{array}{c}\mathrm{IRSL}_{290} \\
(\mathrm{~g}<0.1) \\
576 \pm 23\end{array}$ & $=$ & $128 \pm 18$ \\
\hline \multirow{2}{*}{$\begin{array}{c}\text { Punta } \\
\text { Langosteira }\end{array}$} & \multirow{2}{*}{$3.7 \pm 0.6$} & \multirow{2}{*}{$18 / 26$} & & & $\begin{array}{c}\text { IRSL }_{50} \\
(\mathrm{~g}=0.5) \\
352 \pm 16\end{array}$ & $95 \pm 16$ & $100 \pm 16$ \\
\hline & & & $11 \pm 2$ & $<5$ & $\begin{array}{c}\mathrm{IRSL}_{290} \\
(\mathrm{~g}<0.1) \\
484 \pm 51\end{array}$ & $=$ & $131 \pm 6$ \\
\hline \multirow{2}{*}{ Bornalle } & \multirow{2}{*}{$3.6 \pm 0.4$} & \multirow{2}{*}{$17 / 30$} & & & $\begin{array}{c}\text { IRSL }_{50} \\
(\mathrm{~g}=2.3 \pm 0.5) \\
499 \pm 29\end{array}$ & $139 \pm 17$ & $176 \pm 25$ \\
\hline & & & $19 \pm 3$ & $<5$ & $\begin{array}{l}\mathrm{IRSL}_{290} \\
(\mathrm{~g}=1.0) \\
600 \pm 31\end{array}$ & $151 \pm 8$ & $166 \pm 9$ \\
\hline
\end{tabular}

\section{Discussion}

The existence of climbing dunes (present or fossil) on the coastal cliffs of Galicia (NW Spain) can only be explained by notable aeolian accretion processes that were exacerbated by the topographic effect of a sea level lower than that of the present day [1]. For this reason, knowing the age of its formation is a decisive factor in extending our knowledge of coastal evolution during the regressive cold episodes (glacials) at the end of the Quaternary. In recent years, thanks to the possibility of applying absolute dating techniques to siliciclastic coastal deposits $[3,14,37]$, the problem of the chronology of the coastal evolution of Galicia at the end of the Pleistocene has been re-addressed. In the case of the coastal aeolianites, the previous characterisation of these deposits by Gutiérrez-Becker [1] was key to prove their aeolian origins as climbing dunes. The dating of some of these fossil outcrops by OSL [20] has allowed us to extend the Holocene transgressive model [10], in which the mobilisation of aeolian materials towards the continent as the sea level rose from the end of the Upper Pleistocene was proposed.

As an example, the study and dating of the Figueiras aeolianite outcrop on Monteagudo Island (Cíes Islands, Pontevedra, Galicia) [8] has allowed (i) the establishing of the source area of aeolian sediments, (ii) the defining of their evolution since the end of the last glacial episode, (iii) the justification of the location of the aeolianites on the present coastline and (iv) the reinterpretation of isolated data from the local sedimentary record as a whole. This old climbing dune, currently located at $+40 \mathrm{~m}$ (apsl) on a granitic ridge surrounded by sea (Monteagudo Island), has a lower limit of $35 \mathrm{ka}$ and an upper limit 
of $17 \mathrm{ka}$. Considering the global record, this dune has been active since the end of the last regressive cold episode (MIS2) [38,39], coinciding with a maximum (marine) regressive episode of $-120 \mathrm{~m}$ (bpsl) [40]. Local studies have established a sea level of below $-100 \mathrm{~m}$ (bpsl) [41] $20 \mathrm{ka}$ ago, although glacial ablation episodes were already occurring in the inland mountains of Galicia during this period [42,43], suggesting that the Upper Pleistocene glacial maximum was earlier and probably had a lower sea level. These sand dunes were, therefore, mobilised towards the mainland by prevailing S-SE winds [18] from a strip of emerged continental shelf (the source area of the sand supply) that was several kilometres wide [19] (Figure 5). The location of this old climbing dune is evidence that the dune fields were able to overcome the completely emerged relief of the Cíes Islands, which was more than $300 \mathrm{~m}$ above sea level at the time, and also cover part of the emerged relief that today forms the current Ria de Vigo. Subsequently, as the sea level rose during the post-glacial transgression, aeolian mobilisation was progressively reduced due to the lack of sand supply. This circumstance explains the placement of dunes on the present-day coastline on the eastern slope of the Cíes Islands, as evidenced by the chronology of the dune fields formed between $25 \mathrm{ka}$ and $4 \mathrm{ka}$ [9] both on the coast of Galicia and on the northern coast of Portugal $[18,44-46]$. All of this suggests that the process of the accumulation and mobilisation of sandy materials during regressive cold episodes could be extrapolated to the entire Atlantic coast of the NW Iberian Peninsula.

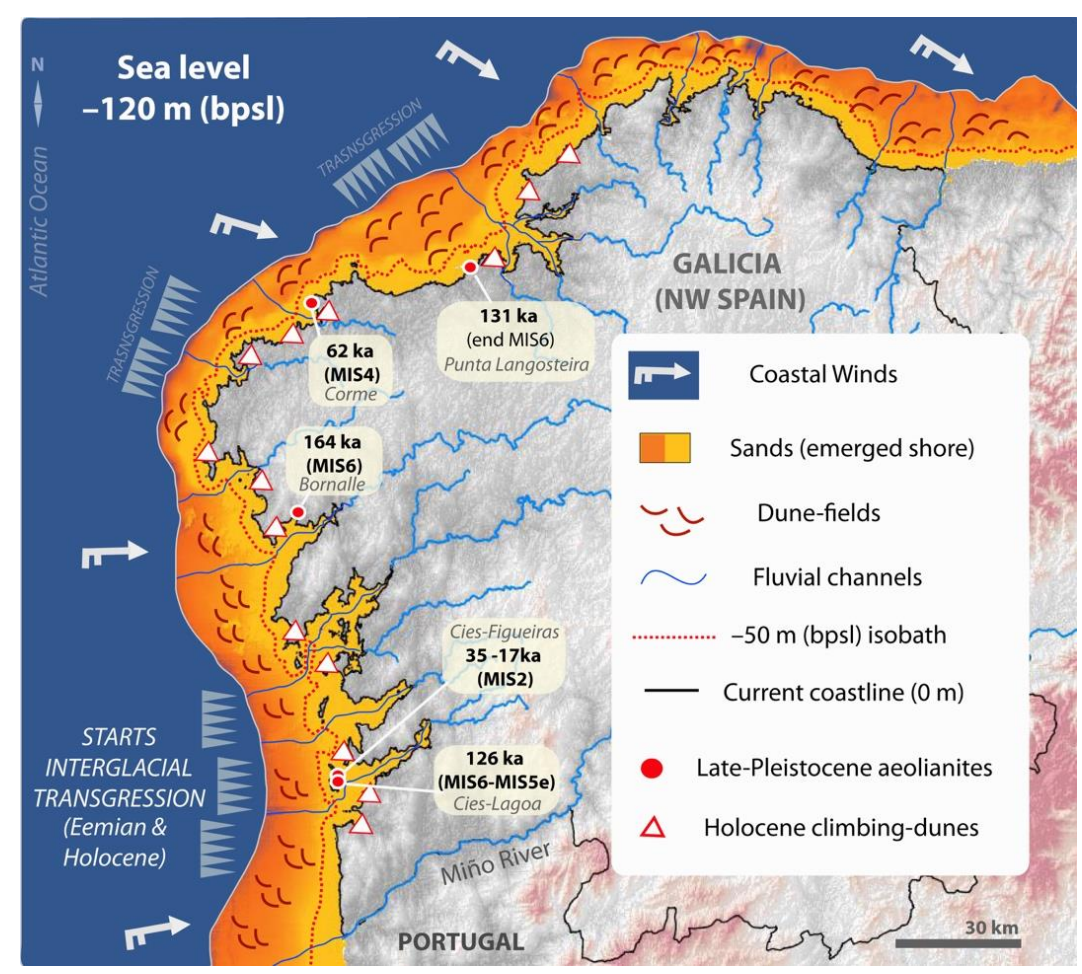

Figure 5. Climbing dunes and the evolution of the Atlantic coast of Galicia (NW Spain) during Late Pleistocene regressive cold events. A model map of the coastline at $-120 \mathrm{~m}$ and $-50 \mathrm{~m}$ (bpsl) (blue area and red dotted line, respectively) during MIS6, MIS4 and MIS2 [39,40] and the emerged strip of the continental platform covered by sand [16] (orange and yellow areas), using the bathymetric data from EDMOnet [19]. Sand was transported by coastal winds as proposed by Costas et al. [18]. The red dots show the location of the IRSL-dated climbing dunes in this paper and the climbing dune from Figueiras, in the Cíes Islands, [8] dated by OSL as from 35 ka to 17 ka (MIS2) [39]. All of these fossil climbing dunes were located in the area of the current coastline, from a lower sea level. Dune fields (hypothetically represented) were mobilised towards the continent during the Eemian and Holocene transgressions, only stopping when the sea reached its present level and flooded the emerged continental shelf (as evidenced by the relic dunes preserved on the current coast of Galicia: white triangles). 
The chronology established in this paper also allows us to apply the model of old climbing dunes formation to the different cold stages of the Late Pleistocene [14]. Considering the climatic record of the Earth (Figure 6), the formation of the Bornalle aeolianite coincided with a positive sea level fluctuation throughout the first half of the MIS6 cold stage, which started from a sea level below $-50 \mathrm{~m}$ (bpsl) [40]. During this period, and as a reference, alluvial sedimentation processes developed $180 \mathrm{ka}$ ago at the present mouth of the Ulla River in the Ria de Arousa (Galicia, Pontevedra) (Figure 1), which have been ascribed to regressive episodes [47]. This also coincides with the chronology [3] of some of the lower terrace levels of the Sil-Miño fluvial system (Pontevedra, Galicia, Spain) (Figure 1) and with some of the dated coastal fluvial levels in northern Portugal [48]. The formation of the Punta Langosteira aeolianite has been ascribed to the end of the penultimate glacial episode of the Pleistocene, when the maximum regressive levels were similar to those achieved at the end of the last glacial episode (Figure 6); and it continued during the Eemian post-glacial transgression [49].

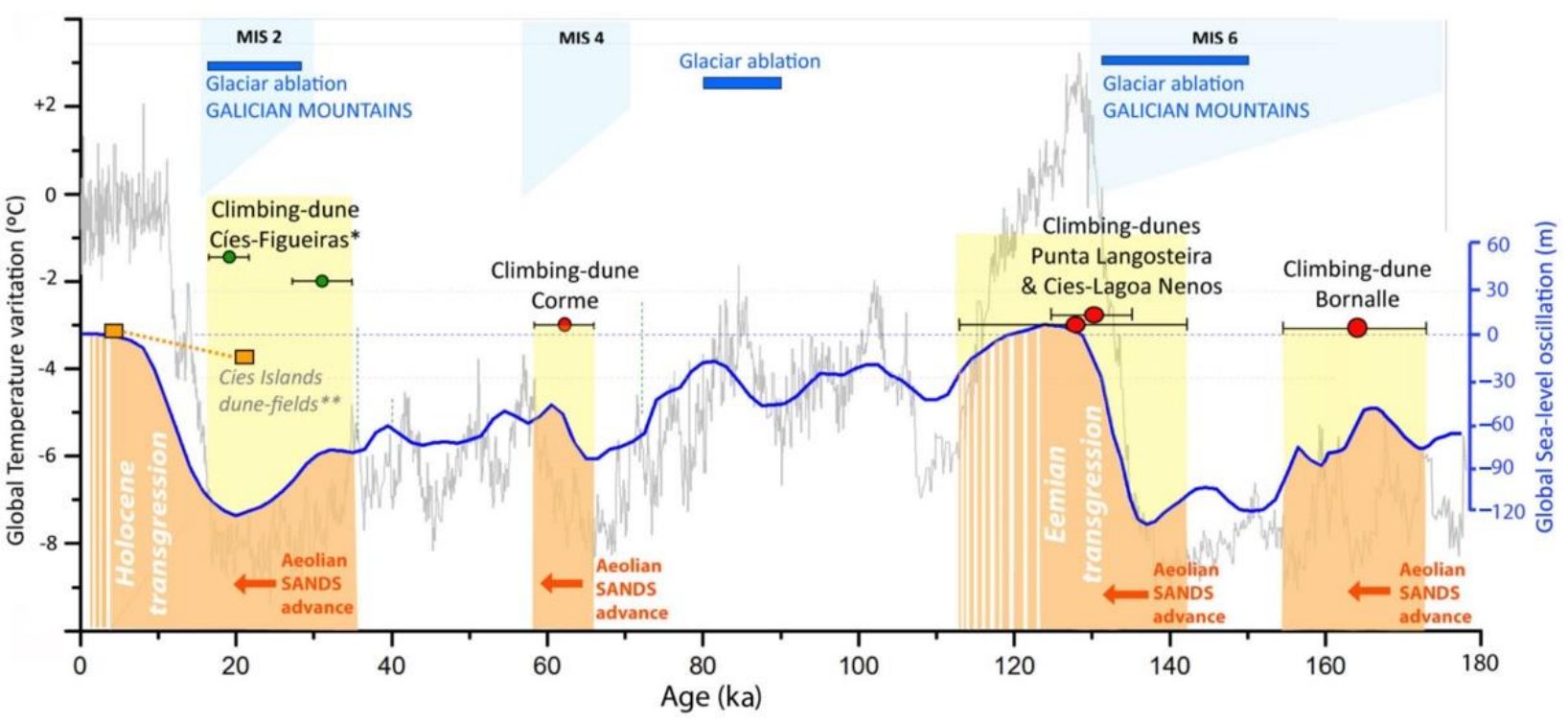

Figure 6. $180 \mathrm{ka}$ global climatic record and the formation age of the coastal climbing dunes dated by pIR-IRSL. The global temperature variation from Vostok ice cores [38], global sea level oscillation [40] and cold marine isotope stages (MIS6, MIS4 and MIS2) [39]. The formation ages (and error) for the coastal climbing dunes from Punta Langosteira, Corme, Bornalle and Lagoa dos Nenos. The figure also shows the formation age of the climbing dune from Figueiras, in the Cíes Islands-, dated from $35 \mathrm{ka}$ to $17 \mathrm{ka}$ by OSL [8], the formation age of the current dune fields on the Cíes Islands dating back $25 \mathrm{ka}$ to $4 \mathrm{ka}$ [9] and the episodes of glacier ablation in the mountains of Galicia (NW Spain) [42,43].

Considering global glacioesustatic oscillations, the placement of this climbing dune (Punta Langosteira) on the present-day coastline between $+5 \mathrm{~m}$ and $+9 \mathrm{~m}$ (apsl) coincides with a sea level below $-120 \mathrm{~m}$ (bpsl) [40]. This suggests that, as with the Bornalle aeolianite during MIS6, the mobilisation of sand by wind along the strip of emerged continental shelf (Figure 5) reached the middle cliffs that define the current Atlantic coast of this area. The age calculated for the aeolianite from the Lagoa dos Nenos coincided with the MIS6-MIS5e transition. This suggests that, during the Eemian interglacial transgression, this climbing dune connected the islands of Monteagudo and Faro (see aeolianite 4 in Figure 1) in the same way that the dune fields do today [9]. Furthermore, this climbing dune would have been similar to the present-day climbing dunes (they do not receive supplies and are covered by vegetation and present blowout erosional formations) (Figure 3) and would not have been completely eroded by the wind once the aeolian supplies stopped during the maximum transgressive levels of the Eemian. In this sense, it would not be difficult to understand the preservation of this type of aeolian formation during the glacial-interglacial-glacial 
transitions, justifying their small size and their characterisation as thin aeolian wedges [1] Finally, the formation of the Corme aeolianite coincided with the MIS4 cold fluctuation (Figure 6). The oscillation of the sea level during this period [40], established a lowering of about $-50 \mathrm{~m}$ (bpsl) (Figure 5), followed by a rise of about $20 \mathrm{~m}$ at the beginning of MIS3 (Figure 6). Thus, this active climbing dune in the middle of the Upper Pleistocene reached heights above $+70 \mathrm{~m}$ above the sea level at this time and mobilised over several kilometres from the emerged continental shelf (Figure 5).

Therefore, a parallel exists between the aeolian accretion process identified in the Ria de Vigo (the southernmost of the Galician rias) at the end of MIS2 [8] and the processes that led to the advance of the Corme climbing dune and it reaching the inner part of the Ria de Corme and Laxe during MIS4, the formation of the climbing dune in the open coastal area of Punta Langosteira at the end of MIS6 and the formation of the Bornalle climbing dune in the inner part of the Ria de Muros during MIS6. All of these aeolian formations reached the present coastline when the sea level was between -50 and $-100 \mathrm{~m}$ (or even more) below the present one, covering all available surfaces and even overcoming a very steep cliff relief, such as the one that characterised the Atlantic coast of Galicia at that time.

\section{Conclusions}

The pIR-IRSL dating technique was suitable to establish a precise chronology of the aeolianite outcrops studied in this paper, which were characterised as climbing dunes [1]. The formation age of the Bornalle aeolianite, dating back $166 \mathrm{ka}$, coincided with the cold regressive episode MIS6. The formation of the Punta Langosteira and Lagoa dos Nenos aeolianites of $131 \mathrm{ka}$ and $128 \mathrm{ka}$, respectively, took place at the end of the penultimate glacial (MIS6) and throughout the Eemian interglacial period. The formation of the Corme aeolianite took place $62 \mathrm{ka}$ ago, during the MIS4 regressive cold episode.

According to the global climatic record and the local sedimentary record, all of these aeolian materials that are still preserved on the Atlantic coast of Galicia were mobilised from the emerged continental shelf towards the continent at lower sea levels and reached the current coastline. During the Middle and Late Holocene, the process of aeolian accretion along this coast was interrupted as a consequence of the flooding of the sand source areas as the sea reached its present levels, along with the development of blowout erosional forms that degraded the climbing dunes. Considering the chronology established in this paper and the cyclical fluctuations of both the regressive cold episodes and the warmer transgressive episodes at the end of the Quaternary, this circumstance could be extrapolated to the penultimate glacial episode and the Eemian interglacial episode.

Author Contributions: Conceptualisation, C.A.-C., J.R.V.-R. and J.S.-S.; funding acquisition, J.R.V.-R.; methodology, C.A.-C. and J.S.-S.; investigation and resources, C.A.-C. and J.R.V.-R.; supervision, J.R.V.-R. and J.S.-S.; writing, C.A.-C. and J.R.V.-R. All authors have read and agreed to the published version of the manuscript.

Funding: This research was funded and supported by Xunta de Galicia (programmes ED431B 2018/47 and ED431B 2021/17) through the Grupo Interdisciplinar de Patrimonio Cultural e Xeolóxico (CULXEO).

Institutional Review Board Statement: Not applicable.

Informed Consent Statement: Informed consent was obtained from all subjects involved in the study.

Data Availability Statement: The data used in this study were obtained from the doctoral thesis of the first author (C.A-C.) (https:/ / ruc.udc.es/dspace/handle/2183/19810) (accessed on 1 February 2022).

Acknowledgments: We would like to thank José Antonio Fernández Bouzas, director of the PNMTIIAAIslas Cíes, for his permission to visit the park and take samples. We would like to thank the Xunta de Galicia for its support through the Grupo Interdisciplinar de Patrimonio Cultural e Xeolóxico (CULXEO) (programmes ED431B 2018/47 and ED431B 2021/17). We would also like to thank most sincerely the Reviewers and the Editors for their suggestions and comments. 
Conflicts of Interest: The authors declare no conflict of interest. The funders had no role in the design of the study, in the collection, analyses or interpretation of data, in the writing of the manuscript nor in the decision to publish the results.

\section{References}

1. Gutiérrez-Becker, L. Caracterización de los Sistemas Dunares Costeros del NW Ibérico y su Evolución Durante el Cuaternario. Ph.D. Thesis, Universidad de Coruña, A Coruña, Spain, 2008. Available online: https://dialnet.unirioja.es/servlet/tesis?codigo= 45245 (accessed on 1 February 2022).

2. Nonn, H. Les Régiones Cotières de la Galice (Espagne). Etude Géomorpholigique; Publications de la Faculté des Lettres de L’Université de Strasbourg; Foundation Baulig: Paris, France, 1966; Tomo III.

3. Viveen, W.; Braucher, R.; Bourlès, D.; Schoorl, J.M.; Veldkamp, A.; van Balen, R.T.; Wallinga, J.; Fernandez-Mosquera, D.; Vidal-Romani, J.R.; Sanjurjo-Sanchez, J. A 0.65 Ma chronology and incision rate assessment of the NW Iberian Miño River terraces based on 10Be and luminescence dating. Glob. Planet. Change 2012, 94-95, 82-100. [CrossRef]

4. Santos, M.L.; Vidal-Romaní, J.R. La transgresión holocena en la Ria de Ares (A Coruña, Galicia, España). Datos cronológicos, sedimentarios y geomorfológicos. In Proceedings of the $3^{\text {a }}$ Reunião do Quaternario Ibérico, Coimbra, Portugal, 27 September-1 October 1993; pp. 339-345.

5. Vidal-Romaní, J.R.; Santos-Fidalgo, L.; López-Cancelo, L.; Mosquera-Santé, M.J.; Leira-Campos, M. Storminess Variation along the Atlantic Seaboard of Europe over the Last 2000 Years: Holocene Storminess from Coastal Barriers in North-West Spain; Internal Report; Universidade da Coruña: A Coruña, Spain, 2000.

6. López-Cancelo, L. Cambios Paleoambientales en el NW Peninsular, Durante el Holoceno, Determinados a Partir del Estudio de Foraminíferos Bentónicos. Ph.D. Thesis, Universidad de A Coruña, A Coruña, Spain, 2004. Available online: https: / / dialnet. unirioja.es/servlet/tesis?codigo $=47918$ (accessed on 1 February 2022).

7. Nieto, M.I.; Vidal-Romaní, J.R. Niveles marinos y depósitos continentales antiguos en el borde costero entre Cabo Prior y Cabo Prioriño (A Coruña, Galicia, España). Cad. Lab. Xeol. Laxe 1989, 14, 67-78.

8. Arce-Chamorro, C.; Vidal-Romaní, J.R.; Sanjurjo-Sánchez, J. Islas Cíes: Una trampa eólica en la Ría de Vigo (NO de la Península Ibérica) al final del último glacial. Estudio del afloramiento de eolianitas de la Isla de Monteagudo (Cíes, Pontevedra, Galicia). Geogaceta 2021, 70, 3-6.

9. Costas, S.; Muñoz-Sobrino, C.; Alejo, I.; Pérez-Arlucea, M. Holocene evolution of a rock-bounded barrier-lagoon system, Cies Islands, northwest Iberia. Earth Surf. Proc. Land. 2009, 34, 1575-1586. [CrossRef]

10. Vidal-Romaní, J.R.; Grandal-d 'Anglade, A. Nota sobre la última transgresión marina en la costa de Galicia. Cad. Lab. Xeol. Laxe. 2018, 40, 229-246. [CrossRef]

11. Fick, S.E.; Hijmans, R.J. WorldClim 2: New 1-km spatial resolution climate surfaces for global land areas. Int. J. Climatol. 2017, 37, 4302-4315. [CrossRef]

12. Jackson, D.W.T.; Costas, S.; González-Villanueva, R.; Cooper, A. A global 'greening' of coastal dunes: An integrated consequence of climate change? Glob. Planet. Change 2019, 182, 103026. [CrossRef]

13. Flor-Blanco, G.; Alcántara-Carrió, J.; Jackson, D.W.T.; Flor, G.; Flores-Soriano, C. Coastal erosion in NW Spain: Recent patterns under extreme storm wave events. Geomorphology 2021, 387, 107767. [CrossRef]

14. Trindade, M.J.; Prudêncio, M.I.; Sanjurjo-Sánchez, J.; Romaní, J.R.V.; Ferraz, T.; Mosquera, D.F.; Dias, M.I. Post-depositional processes of elemental enrichment inside dark nodular masses of an ancient aeolian dune from A Coruña, Northwest Spain. Geologica Acta 2016, 11, 231-244. [CrossRef]

15. Ottman, F.C. Introducción a la Geología Marina y Litoral; Editorial EUDEBA: Buenos Aires, Argentina, 1967; 287p.

16. Rey-Salgado, J. Relación Morfosedimentaria entre la Plataforma Continental de Galicia y las Rías Bajas y su Evolución durante el Cuaternario; Instituto Español de Oceanografía: Madrid, Spain, 1993; 233p.

17. De Vicente, G.; Vegas, R. Large-scale distributed deformation controlled topography along the western Africa -Eurasia limit: Tectonic constrains. Tectonophysics 2009, 474, 124-143. [CrossRef]

18. Costas, S.; Jerez, S.; Trigo, R.M.; Bogle, R.; Rebêlo, L. Sand invasion along the Portuguese coast forced by westerly shifts during cold climate events. Quat. Sci. Rev. 2012, 42, 15-28. [CrossRef]

19. EDMOnet Bathymetry Consortium. EMODnet Digital Bathymetry (DTM). 2018. Available online: https://doi.org/10.12770/1 8ff0d48-b203-4a65-94a9-5fd8b0ec35f6 (accessed on 1 February 2022).

20. Arce-Chamorro, C. Datación por Luminiscencia de Depósitos Fluviales y Eólicos en el Margen Occidental de Galicia. Ph.D. Thesis, Universidade da Coruña, A Coruña, Spain, 2017; p. 399. Available online: http://hdl.handle.net/2183/19810 (accessed on 1 February 2022).

21. Buylaert, J.P.; Murray, A.S.; Thomsen, K.J.; Jain, M. Testing the potential of an elevated temperature IRSL signal from K-feldspar. Radiat. Meas. 2009, 44, 560-565. [CrossRef]

22. Thiel, C.; Buylaert, J.P.; Murray, A.; Terhorst, B.; Hofer, I.; Tsukamoto, S.; Frenchen, M. Luminiescence dating of the Stratzing loess profile (Austria)-Testing the potential of an elevated temperature post-IR IRSL protocol. Quat. Int. 2011, 234, 23-31. [CrossRef]

23. Auclair, M.; Lamothe, M.; Huot, S. Measurement of anomalous fading for feldspar IRSL using SAR. Radiat. Meas. 2003, 37, 487-492. [CrossRef] 
24. Huntley, D.J.; Lamothe, M. Ubiquity of anomalous fading in K-feldspars and the measurement and correction for it in optical dating. Can. J. Earth. Sci. 2001, 38, 1093-1106. [CrossRef]

25. Burow, C.; Kreutzer, S.; Dietze, M.; Fuchs, M.; Fischer, M.; Schmidt, C.; Brückner, H. RLumShiny-A graphical user interface for the R Package 'Luminescence'. Ancient TL 2016, 34, 22-32.

26. Guérin, G.; Mercier, N.; Adamiec, G. Dose rate conversion factors. Ancient TL 2011, 29, 5-8.

27. Huntley, D.J.; Baril, M.R. The K content of K-feldspars being measured in optical dating or in thermoluminescence dating. Ancient TL 1997, 15, 11-13.

28. Mejdahl, V. Internal radiactivity in Quartz and felspar grains. Ancient TL 1987, 5, 10-17.

29. Prescott, J.R.; Hutton, J.T. Cosmic ray contribution to dose rates for luminescence and ESR dating: Large depths and long-term time variations. Radiat. Meas. 1994, 23, 497-500. [CrossRef]

30. Guérin, G.; Mercier, N. Preliminary insight into dose deposition processes in sedimentary media on a scale of single grains: Monte Carlo modelling of the effect of water on the gamma dose rate. Radiat. Meas. 2012, 47, 541-547. [CrossRef]

31. Nathan, R.; Thomas, P.J.; Murray, A.S.; Rhodes, E.J. Environmental dose rate heterogeneity of beta radiation and its implications for luminescence dating: Monte Carlo modelling and experimental validation. Radiat. Meas. 2003, 37, 305-313. [CrossRef]

32. Ivanovich, M.; Harmon, R.S. Uranium Series Desequilibrium: Applications to Earth, Marine and Environmental Sciences, 2nd ed.; Clarendon Press: Oxford, UK, 1982; 910p, ISBN 019854278 X.

33. Krebscheck, M.R.; Uieser, U.; Stolz, W. Optical dating: Some luminescence properties of natural feldspars. Radiat. Prot. Dosimetry 1996, 66, 407-412. [CrossRef]

34. Pye, K.; Tsoar, H. Aeolian Sand and Sand Dunes; Unwin Hyman Ltd.: London, UK, 1990; p. 396. ISBN 004551125X.

35. Jacobs, Z. Luminescence chronologies for coastal and marine sediments. Boreas 2008, 37, 508-535. [CrossRef]

36. Galbraith, R.F.; Roberts, R.G.; Laslett, G.M.; Yoshida, H.; Olley, J.M. Optical dating of single and multiple grains of quartz from Jinmium rock shelter, northern Australia: Part I. Experimental design and statistical models. Archaeometry 1999, 41, 339-364. [CrossRef]

37. Sanjurjo-Sánchez, J.; Vidal-Romaní, J.R. Problemas nuevos y procedimientos de datación por OSL para los sedimentos litorales del NO de la Península Ibérica. VII Jornadas de Geomorfología Litoral, Oviedo, España. Geotemas 2013, 14, 47-50.

38. Petit, J.R.; Jouzel, J.; Raynaud, D.; Barkov, N.I.; Barnola, J.-M.; Basile, I.; Bender, M.; Chappellaz, J.; Davis, M.; Delaygue, G.; et al. Climate and atmospheric history of the past 420,000 years from the Vostok ice core, Antarctica. Nature 1999, 399, 429-436. [CrossRef]

39. Lisiecki, L.E.; Raymo, M.E. A Pliocene-Pleistocene stack of 57 globally distributed benthic d18O records. Paleoceanography 2005, 20, PA1003. [CrossRef]

40. Waelbroeck, C.; Labeyrie, L.; Michel, E.; Duplessy, J.C.; McManus, J.F.; Lambeck, K.; Balbon, E.; Labracherie, M. Sea-level and deep water temperature changes derived from benthic foraminifera isotopic records. Quat. Sci. Rev. 2002, 21, 295-305. [CrossRef]

41. Mohamed, K.J.; Rey, D.; Rubio, B.; Vilas, F.; Frederichs, T. Interplay between detrital and diagenetic processes since the last glacial maximum on the northwest Iberian continental shelf. Quat. Res. 2010, 73, 507-520. [CrossRef]

42. Vidal-Romaní, J.R.; Fernández-Mosquera, D.; Marti, K.; De Brum-Ferreira, A. Nuevos datos para la cronología glaciar pleistocena en el NW de la Península Ibérica. Cad. Lab. Xeol. Laxe. 1999, 24, 7-29.

43. Vidal-Romaní, J.R.; Fernández-Mosquera, D.; Marti, K. The glaciation of Serra de Queixa-Invernadoiro and Serra do Geres-Xurés, NW Iberia. A critical review and a cosmogenic nuclide (10-Be and 21-Ne) chronology. Cad. Lab. Xeol. Laxe. 2015, 38, 25-44. [CrossRef]

44. Granja, H.M.; Soares de Carvalho, G. Sea-level changes during the Pleistocene-Holocene in the NW coastal zone of Portugal. Terra Nova 1995, 7, 60-67. [CrossRef]

45. Thomas, J.P.; Murray, A.S.; Granja, H.M.; Jain, M. Optical Dating of Late Quaternary Coastal Deposits in Northwestern Portugal. J. Coast. Res. 2006, 24, 134-144. [CrossRef]

46. García-Amorena, I.; Gómez-Manzaneque, F.; Rubiales, J.M.; Granja, H.M.; de Carvalho, G.S.; Morla, C. The Late Quaternary coastal forests of western Iberia: A study of their macroremains. Palaeogeog. Plaeoclimatol. Palaeoecol. 2007, 254, 448-461. [CrossRef]

47. Arce-Chamorro, C.; Vidal-Romaní, J.R. Late-Pleistocene chronology of coastal fluvial deposits at the mouth of the Ulla River in the Ría de Arousa (Galicia, NW Spain) by OSL dating. Cad. Lab. Xeol. Laxe 2021, 43, 61-88. [CrossRef]

48. Ribeiro, H.; Pinto de Jesus, A.; Sanjurjo-Sánchez, J.; Abreu, I.; Romani, J.R.V.; Noronha, F. Multidisciplinary study of the quaternary deposits of the Vila Nova de Gaia, NW Portugal, and its climate significance. J. Iber. Geol. 2019, 45, 1-11. [CrossRef]

49. Shackleton, N.J.; Sánchez-Goñi, M.F.; Pailler, D.; Lancelot, Y. Marine Isotope Substage 5e and the Eemian Interglacial. Glob. Planet. Change 2003, 36, 151-155. [CrossRef] 